\title{
A POLYPHONIC DICTATION AS A FORM OF WORK ON HARMONIOUS HEARING
}

\author{
Galina Zavadska \\ Ilona Bagele \\ Daugavpils University, Latvia
}

\begin{abstract}
Harmonious hearing is one kind of musical hearing that manifests itself in relation to a simultaneous sounding of consonances (a complex of sounds of different pitch) and mutual relationships between consonances.

A polyphonic music dictation is one of the most important and complicated forms of work for the development of harmonious hearing during sol-fa classes at a higher education establishment. The skill of remembering a polyphonic dictation and quickly fixing the heard music involves an organic combination of listening to separate sounds and to the harmonious vertical of sounds, as well as their functional interaction, which promotes the development of musical thinking in general.

The given research is concerned with the comparison of the methodological recommendations for fixing polyphonic dictations, as well as with working out the algorithm of the polyphonic dictation notation.

Research aim: to study the principles of a polyphonic dictation and specificity of its notation. Work on a polyphonic dictation implies an organic combination of hearing separate voices and the harmonious vertical, comprehending each moment of sounding and their functional-logical interconnection.
\end{abstract}

Keywords: polyphonic dictation, harmonious hearing, notation algorithm.

\section{Introduction}

Musical hearing is an especially complicated phenomenon: it is a comprehensive complex incorporating different facets of intellect. Musical hearing has different forms, kinds and infinitively many individual qualities (Zavadska, 2016). The development of musical hearing has always been the basis of music education, which takes place while acquiring different kinds of musical activity. According to B. Teplov (Теплов, 1947), harmonic hearing is one kind of musical hearing and it involves the perception of consonance, ability to simultaneously perceive numerous sounds as one whole. Such kind of hearing is essential for all musicians, since the regularities of musical thinking are principally based on laws of harmonic degrees. Like any kind of hearing, harmonic hearing develops and improves just during the process of a musical 
activity: its development is enhanced by a polyphonic music, especially - by polyphonic compositions.

A polyphonic dictation is one of the work forms for the development of harmonic hearing at sol-fa lessons. Praxis shows that hearing, writing and analysis of a polyphonic dictation are quite a complicated process. Writing of a polyphonic dictation well requires interaction between different factors: the presence of musical memory, a developed sense of mode and rhythm, and also knowledge in the sphere of notation.

Work on a polyphonic dictation implies an organic combination of hearing separate voices and the harmonious vertical, comprehending each moment of sounding and their functional-logical interconnection.

Research aim: to study the principles of a polyphonic dictation and specificity of its notation.

\section{A Musical Dictation}

A musical dictation implies writing down by ear one-, two-, three- and fourvoice musical structures. This is one of the forms of developing musical hearing. A musical dictation may be performed by a voice, on the piano or some other instrument, and then is written down in notation. The dictation may be recorded from memory (writing down a well-known, familiar music), during listening to music (e. g. writing down a folk song) and in conditions of special classes during a sol-fa lesson.

A musical dictation involves comprehending such elements as:

- mode;

- harmony;

- voice leading

- rhythm;

- musical form;

- instrumentation - in a timbral dictation.

The goal of a musical dictation is to train the skills of immediately converting the perceived musical images into precise aural perceptions and fixing them as quickly as possible in notation. The main task of the dictation is the formation and development of learners' musical-logical thinking, memory, attention and sense of style.

The importance of a musical dictation is not restricted only to training skills of writing down music. A dictation is a complicated psychological act: apart from a complex of aural skills, a successful writing of a dictation requires involvement of several psychological factors, such as memory, attention, ability of focused 
listening, activeness. The abilities, needed to write a musical dictation well, develop especially intensively just in the process of work on a musical dictation.

Writing a musical dictation is the best form of how to analyze the heard musical material. It is the main result of knowledge and skills, which determines the level of learner's musical-aural development. The skill of writing dictations is the ability of combining different previously acquired elements into one whole. The level of mastery of recording dictations depends on the degree to which these elements have been acquired.

G. Shatkovsky (Шатковский, 2010) singles out three principal tasks of work on writing down a musical dictation:

1) To establish the connections between the analysis, comprehension, and recording music on the basis of the theoretical knowledge acquired before.

2) To enhance the development of inner hearing and musical memory.

3) Practical acquiring and reinforcement of theoretical concepts and experience gained in the result of learner's practical musical activity.

There are a lot of different kind of musical dictations. E. Joffe (Joffe, 1991) distinguishes such as:

- $\quad$ short flash-dictations;

- $\quad$ recording of familiar melodies without playing them (self-dictations);

- a dictation with a fixed pitch and a dictation in a free tonality;

- a preliminary dictation which is written in parts;

- a dictation "with mistakes";

- a rhythmic dictation;

- an oral dictation;

- a dictation - variations.

The skill of writing down a polyphonic dictation develops only in case the skill of writing down a melodic (single-voice) dictation is developed well enough, which, in turn, is indicative of a higher developmental degree of musical hearing.

\section{A Polyphonic Dictation}

Work on a polyphonic dictation implies an organic combination of hearing separate voices and the harmonic vertical, understanding every moment of sounding as well as their functional-logical interconnections.

The first stage of work on a polyphonic dictation is a two-voice dictation. There are several kinds of two-voice dictations:

1) both melodies develop in one rhythm;

2) the melody in the upper voice develops rhythmically, while that in the lower voice leading progresses by steady lengths;

3) melodies develop on the basis of imitating two-voice (canon); 
4) supporting two-voice dictation.

At recording two-voice dictations, different kinds of voice leading are applied: parallel, opposite and indirect.

The examples of melodies of a supporting voice type are a methodologically convenient form for the transition from one-voice dictation to a two-voice dictation. They involve using the skill of writing down a one-voice leading melody, and simultaneously organize hearing the sound vertical at the moment of the appearance of two-voice. Besides, the possibility of writing down each voice separately is almost excluded, since voices sometimes merge, and sometimes divide into two.

At first, these dictations are written down on one line and attention is paid to:

1) fixing intervals on the strong parts of the bar, paying attention to its harmonic sounding;

2) identifying the line of each voice, especially the lower one, at the place where voices are mobile;

3) controlling the harmonic sounding along the vertical, especially in cadence constructions;

4) at recording the examples with harmonic bass, the ability to direct one's attention towards comprehending mode-functional interconnections, understanding the structure of the example.

\section{The Algorithm of Writing down a Dictation}

Hearing, writing down and analyzing a polyphonic dictation develop students' knowledge and skills in general. The skill of writing down a polyphonic dictation shows student's ability of combining multiple elements into one whole. Writing down the music text of the dictation requires the skills as follows:

- skill of memorizing the perceived music text;

- $\quad$ skill of quickly fixing the heard music text;

- skill of working out the algorithm of writing a dictation.

The skill of memorizing a polyphonic dictation and quickly fixing the heard music text involves the ability of hearing the organic combination of separate sounds and the harmonic sound vertical, as well as the functional interaction between them, which, on the whole, contributes to the development of musical thinking.

The algorithm of writing down a polyphonic dictation shown in Table 1 has been worked out on the basis of sol-fa teaching traditions at Latvian music schools and higher education institutions established by taking into account the recommendations made by Latvian music theoreticians (Kārklinšs, 1963; 
Grauzdina, 1975; Joffe, 1991), as well as on findings in the pedagogical experience of the author of the given paper.

Table 1 Algorithm of writing down a polyphonic dictation (Zavadska, 2015)

\begin{tabular}{cl}
\hline $\mathrm{Nr}$ & \multicolumn{1}{c}{ Stages of writing a polyphonic dictation } \\
\hline 1 & $\begin{array}{l}\text { Before writing a dictation, to establish the tonality, time, metro-rhythmic } \\
\text { peculiarities, structure, phrases, caesuras }\end{array}$ \\
\hline 2 & $\begin{array}{l}\text { To establish the relations between modes for individual stages of a dictation: } \\
\text { - to write down the initial and final sound of each phrase; } \\
\text { - to clarify the developmental principles of the music material (repetitions, } \\
\text { sequences, imitations, variations, expansions etc.); } \\
\text { - to catch alliterations, chromatisms, to be able to identify and fix stable } \\
\text { degrees in the melody of the upper voice }\end{array}$ \\
& $\begin{array}{l}\text { To write down the melody of the upper voice, if possible, with rhythm and } \\
\text { bar-lines; to fix and recognize intervals and chord sounds caught in some parts } \\
\text { (in heavy parts of time); paying attention to the harmonic sounding, to catch } \\
\text { consonances and/or dissonances, triads, their inversions, consonances of the } \\
\text { non-thirds }\end{array}$ \\
\hline 4 & $\begin{array}{l}\text { To write down the upper voice - the second voice in a two-part, the third } \\
\text { voice (harmonic bass) in a three-part dictation }\end{array}$ \\
\hline 5 & $\begin{array}{l}\text { To write down the second voice in a three-part dictation, catching the common } \\
\text { chord sounds and not losing the sense of the mode }\end{array}$ \\
\hline 6 & $\begin{array}{l}\text { On the basis of auditory perceptions, to independently check the sounding of } \\
\text { the harmonic vertical, keeping the metro-rhythm in the basic parts of the bar } \\
\text { and in cadences }\end{array}$ \\
\hline
\end{tabular}

The algorithm of writing down a polyphonic dictation consists of six stages.

Stage 1. Having listened to the music text for the first time before writing a dictation, the learners do not write it down yet: they only listen to it and try to gain a clear perception of the imagery content of music in general, of its character, melodic progression; they identify the tonality of a polyphonic dictation, time, and metro-rhythmic peculiarities. After they have listened to music for the second time, they identify the structure, phrases and caesuras.

Stage 2. A draft recording. It begins with writing down separate phrases, cadential constructions; the developmental principles are defined (sequential, variational, polyphonic), the presence of repeated motifs and phrases is identified, the mode meaning of initial and final intonations is clarified, the support tones (sounds) are established. (At this stage, playing of a polyphonic dictation may differ from the previous one: tempo might be slightly slower, but not to the extent for the music example to lose its musical sense; phrasing sometimes might be a little bit accentuated).

Stage 3. The recording of the upper voice (soprano) is done within the bars marked on the staff (since the structure of a polyphonic dictation is clearly 
defined). After marking the bar lines and finishing the preliminary outline placing the notes according to their pitch - grouping according to the length is done.

Stage 4. At recording a lower voice in a two-three-voice dictation it is important to be able to direct one's attention towards comprehending functional interconnections, towards understanding the harmonic structure of the given melody.

Stage 5. The most difficult task of a polyphonic dictation is recording the middle voice. When recording the middle voice, it is necessary to control the harmonic sounding along the sound vertical, especially at support parts and moments of finishing those or other parts of form (in cadential constructions).

Stage 6. At the last finishing stage, on the basis of aural perceptions, everything that has been unclear is being specified and made absolutely clear; "bowings" and nuances are marked; phrasing leagues are put, pitch line and rhythmic pattern of every voice are checked.

The whole process of recording comprises three stages: from a general perception - to the analysis-specification - and again back to the whole image, which has now been completely understood.

The developed stages of recording a polyphonic dictation have been verified in practice during the pedagogical process, however these stages are not claimed as the only possible. There are several other methodological recommendations for recording polyphonic dictations, for instance, the "fragmental" French methodology (Desportes, 1970) based on fixing the fragments of music of a polyphonic dictation. According to this methodology, the dictation is played by two-time fragments, each being repeated only twice; then, during every next time of playing, all previously performed bars are added to the specific fragment. This type of writing down a dictation is controversial, since a fragmental recording type implies fixing music just during the time when a fragment sounds (it is like taking down in shorthand); as a result the perception of a dictation as a whole piece is lost, and this makes a negative impact on the development of students' musical memory and thinking.

According to the method offered by A. Ostrovsky (Островский, 1954), at first, listening to a harmonic two-voice piece of a rigorous type (a sequence of intervals), students have to write down only the names of intervals, without writing down specific notes. However, this method limits learners' perception and does not direct their consciousness towards hearing the melodic origin of music.

In his manual "1000 Examples of a Musical Dictation" N. Laduchin (Ладухин, 1981) proposes to record a two-voice dictation by "voices", e. g. the line of every voice along the horizontal. Besides, merging of the two melodies involves only time and rhythm aspects. Although this method is useful in practice at the first stage, it does not promote the development of learners' harmonic 
hearing and is not based on acquiring the understanding of the phonic aspect of harmonic intervals.

As an example of a polyphonic (two-voice) dictation we will analyze a fragment of Barcarolle melody from the opera "The Tales of Hoffmann" by J. Offenbach. When listening to the fragment for the first time, students were shown a video fragment where the piece was sung by the well-known singers Elinna Garanča and Anna Netrebko (from Internet http://www.youtube.com/ watch? $\mathrm{v}=\mathrm{Hdc} 2 \mathrm{zNgJIpY}$ ). Watching the video made the students more active, though more attention was devoted to a visual rather than to the audio perception. In authors' opinion, the demonstration of qualitative video recordings entails aesthetic pleasure of students; creates the opportunity of speaking about the educational aspect - pride in the artist of one's own country. When the dictation was played next eight times, the fragment of Barcarolle was played on the piano by a teacher. The tonality of a dictation was defined ( $D$ dur, defining it by the sound "la"), the time $-6 / 8$. Then the structure was analyzed: one period in one tonality (16 bars which consist of two sentences ( 8 bars +8 bars) with phrases which recur ( 4 bars +4 bars/ 4 bars +4 bars). The basis of a functional formula of two-voices in this dictation is the vertical of the third, which is typical of classical music (see Fig. 1).

\section{A fragment of Barcarolle}

J.Offenbach
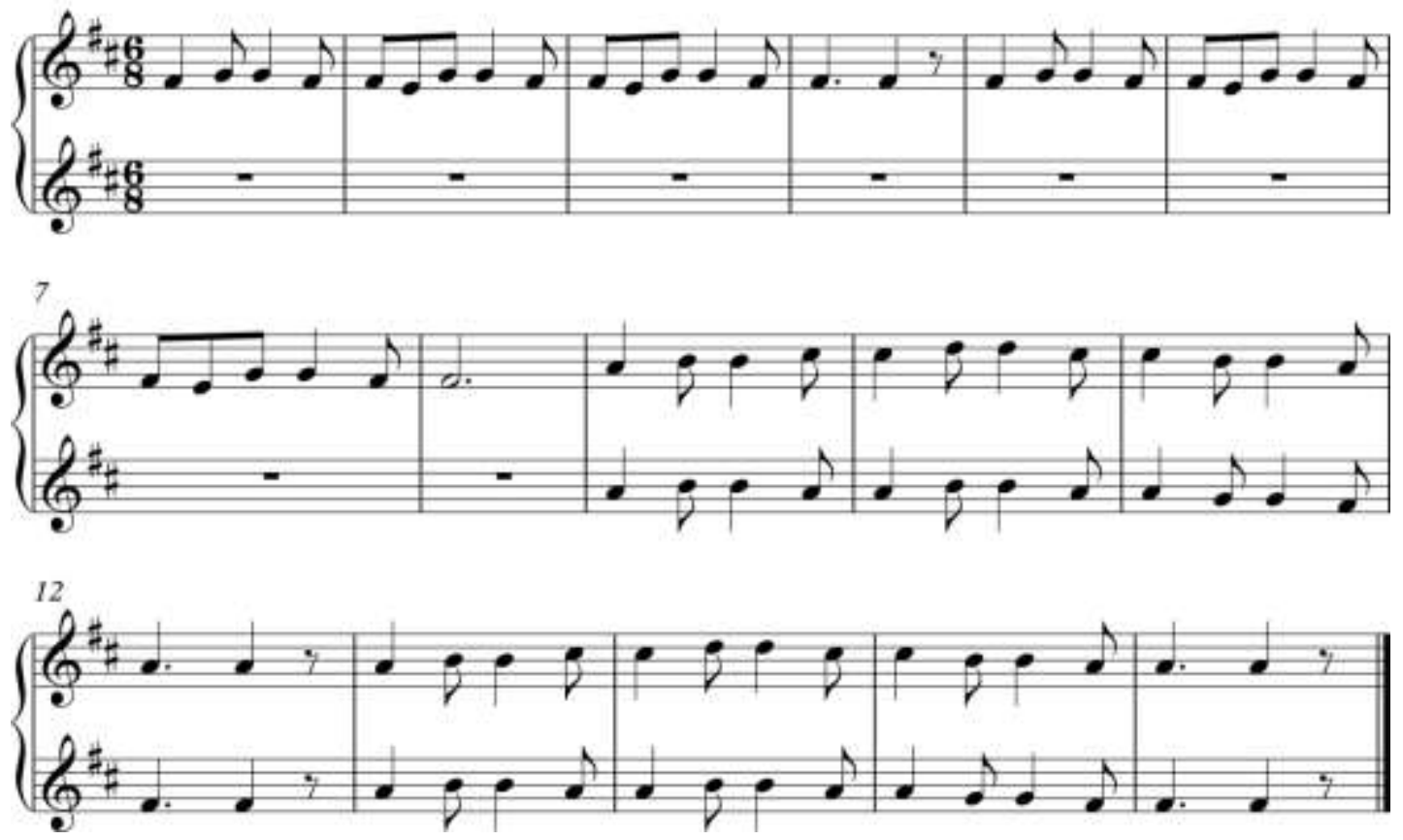

Fig.1 A fragment of Barcarolle melody from the opera "The Tales of Hoffmann" by J. Offenbach 
The perception and recording of polyphonic music is a new quality of harmonic hearing.

\section{Conclusions}

- A polyphonic dictation is one of the forms of work on the development of harmonic hearing. The skill of writing down a polyphonic dictation develops only in case the skill of writing down of a melodic dictation is developed well enough.

- $\quad$ For recording the music text of a polyphonic dictation necessary are such skills as: the skill of memorizing the perceived music text, the skill of being able to quickly fix the heard music text, the skill of working out the algorithm of writing down a dictation.

- The algorithm of recording a polyphonic dictation was worked out on the basis of sol-fa teaching traditions in Latvian music school and higher education institutions and it consists of six stages: the preliminary analysis, draft recording, recording of the upper voice, recording of the lower voice, recording of the middle voice, and the stage of verifying and synthesis.

Polyphonic dictations sharpen the learners' perception by ear of the tight links between the sound vertical and sound horizontal in music, they develop harmonic hearing and the skill of writing down music in all of its diversity.

\section{References}

Desportes, Y. (1970). Comment former l'oreille musicale. Paris: Editions Max Eschig.

Grauzdin̄a, I. (1975). Dzirdes analīze bērnu mūzikas skolu solfedžo nodarbībām. [Analysis of Hearing for Sol-fa Classes at Children Music Schools] Rīga: Mācību iestāžu metodiskais kabinets.

Joffe, J. (1991). Muzikālās dzirdes attīstības cel̦i. [Ways of the Development of Musical Hearing]. Rīga: Zvaigzne.

Kārklin̄š, L. (1963). Mūzikas teorētisko priekšmetu mācīšanas metodika. [Teaching Methodology of Theoretical Subjects in Music] Rīga: Latvijas Valsts izdevniecība.

Zavadska, G. (2015). The development of future music teachers' harmonic hearing in a higher education establishment. Summary of the thesis for obtaining doctoral degree in pedagogy. Retrieved 16.11.2016 from http://du.lv/wp content/uploads/2015/12/ Zavadska_kopsavilkums.pdf

Zavadska, G. (2016). Nature and characterization of harmonious hearing. In A. Šlahova (Ed.), Scientific Articles of $9^{\text {th }}$ International Conference "Person. Color. Nature. Music". Daugavpils: Art Teacher Union in co-operation with Daugavpils Mark Rothko Art Centre and Faculty of Art of Shiauliai University (Lithuania), 165-173.

Ладухин, Н. (1981). 1000 примеров музыкального диктанта на 1, 2 и 3 голоса. Пособие к систематическому развитию слуха. [1000 Examples of a Musical Dictation on 1, 2, and 3 Voices. A Manual for a Systematic Development of Hearing]. Москва: Музыка. 
SOCIETY. INTEGRATION. EDUCATION

Proceedings of the International Scientific Conference. Volume IV, May $26^{\text {th }}-27^{\text {th }}$, 2017. 168-176

Островский, А. Л. (1954). Очерки по методике теории музыки и сольфеджио. [Essays on the methodology of music theory and ear training]. Ленинград: Государственное музыкальное издательство.

Теплов, Б. (1947). Психология музыки и музыкальных способностей. [Music Psychology and Musical Abilities]. Москва, Ленинград: Издательство педагогических наук.

Шатковский, Г. (2010). Развитие музыкального слуха. [The development of Musical Hearing]. Москва: Амрита. 


\section{EKONOMIKA UN SABIEDRĪBAS PĀRVALDĪBA ECONOMICS AND PUBLIC ADMINISTRATION}


